\title{
Petrofizyczne aspekty poszukiwań naftowych na dużych głębokościach
}

\section{Petrophysical aspects of hydrocarbon prospecting and exploitation in deeper targets}

\author{
Piotr Such \\ Instytut Nafty i Gazu - Państwowy Instytut Badawczy
}

\begin{abstract}
STRESZCZENIE: Szanse na stosunkowo duże złoża węglowodorów istnieją w Karpatach oraz na Niżu Polskim w utworach czerwonego spągowca i być może dewonu. Ich cechą wspólną jest zaleganie na głębokościach poniżej 3 km. Duże koszty wierceń na tych głębokościach oraz typ potencjalnych złóż (niekonwencjonalne i o niskich przepuszczalnościach) są przyczynami, dla których problemem zasadniczym jest opłacalność ich eksploatacji. Realna analiza ekonomiczna wymaga opracowania modelu złoża (wraz z charakterystyką petrofizyczną skał, liczbą potencjalnych odwiertów), a ten z kolei wymaga wykonania kompletu badań geofizyki otworowej i kompletu badań laboratoryjnych (petrograficznych, petrofizycznych). Dodatkowo ze względu na głębokości i rodzaj skał takie parametry jak przepuszczalność, przepuszczalność względna, przepływy oryginalnych płynów złożowych czy analizy geomechaniczne muszą być wykonywane w symulowanych warunkach złożowych. Analizy w symulowanych warunkach złożowych trwają bardzo długo, są również kosztowne. Kolejnym parametrem warunkującym opłacalną eksploatację jest ilość węglowodorów, które można pozyskać. Należy również uwzględnić potencjalne szczelinowania. Optymalnym rozwiązaniem byłoby wykonanie wstępnego modelu złoża na podstawie pierwszego wiercenia. Czy jest to możliwe? Tak, jeśli stworzymy odpowiednie bazy danych dla poszczególnych basenów sedymentacyjnych. Warunkiem koniecznym jest istnienie w bazie danych poprawnej statystycznie liczby badań wykonanych w warunkach otworowych oraz wszystkich innych dostępnych badań. Wtedy, wykorzystując metody sztucznej inteligencji, można dokonać wydzielenia klas podobieństwa skał (ang. rock typing), oszacować parametry skał dla całego złoża i przeprowadzić analizę ekonomiczną na podstawie bazy danych z rozwiercanego basenu sedymentacyjnego oraz wyników badań rdzeni i profili geofizycznych z pierwszego odwiertu. Bazy danych powinny rosnąć w miarę prac w poszczególnych basenach sedymentacyjnych. Podsumowując, można stwierdzić, że kluczem dla udostępniania tego typu złóż będą analizy w symulowanych warunkach złożowych i bazy danych (big data) pozwalające na zastosowanie metod sztucznej inteligencji.
\end{abstract}

Słowa kluczowe: duże głębokości, analiza ekonomiczna, warunki złożowe, bazy danych.

ABSTRACT: We are entering the second stage of prospecting hydrocarbons in Poland. The potential volume of gas in various types of unconventional reservoirs is huge. Deep lying sediments in the Carpathians and in the Polish Lowland (the Rotliegend Basin and the Devonian) are prospective gas basins, but it is possible to find them deeper than $3000 \mathrm{~m}$. Additionally, in contrast with shale gas, other types of unconventional reservoirs provide a big chance for profitable exploitation, however it requires application of complex, modern methods of investigation and very careful calculation of all prices connected with facilities of such types of reservoirs. Deeper targets means great drilling costs. Unconventional type means that compressibility of rocks and reservoir fluids, as well as high temperatures and pressures, must be taken into account. These two factors result in the main problem being economical profitability. Real economical analysis is possible after creating a numerical reservoir model with evaluation of the volume of hydrocarbons, the number of necessary wells and the potential production rate. The numerical model requires well logs and laboratory analyses. A part of laboratory analyses must be performed in simulated reservoir conditions. These analyses are expensive and time consuming. So, is it possible to reduce the costs and the time of model creation? For example, is it possible to create a full numerical model on the basis of the first well. Yes, if we have an appropriate data base (date base from the sedimentary basin in which we found a reservoir with a statistically correct number of core analyses performed in simulated reservoir conditions). In such a situation we can apply artificial intelligence methods and rock typing methods and evaluate petrophysical parameters for the whole reservoir. To sum up, the key to proper evaluation and exploitation scheduling will be the analyses performed in simulated reservoir conditions and big data.

Key words: deeper targets, economical analysis, reservoir conditions, data bases.

Autor do korespondencji: P. Such,e-mail: piotr.such@inig.pl

Artykuł nadesłano do Redakcji: 30.04.2020 r. Zatwierdzono do druku: 22.07.2020 r. 


\section{Wstęp}

Problem poszukiwań ropy i gazu na dużych głębokościach jest bardzo aktualny w przypadku polskich firm wydobywczych. Szanse na stosunkowo duże złoża węglowodorów istnieją w Karpatach oraz na Niżu Polskim w utworach czerwonego spągowca i być może dewonu, przy czym problemem zasadniczym jest opłacalność eksploatacji (Such, 2019). Krytycznymi punktami w analizie ekonomicznej będą koszty wierceń, wielkość złóż i ich parametry petrofizyczne.

W pracy przeanalizowano zależności pomiędzy tymi czynnikami, które muszą być spełnione, aby późniejsza analiza ekonomiczna była opłacalna.

\section{Dlaczego duże głębokości}

Jako "duże głębokości" w warunkach polskich przyjmuje się głębokości większe niż $3000 \mathrm{~m}$. Podstawowe poziomy ropo- i gazonośne zalegające na mniejszych głębokościach zostały już w większości rozpoznane i wyeksploatowane. Zostały jeszcze tight gazowe poziomy miocenu przedgórza Karpat, lecz ich zasoby nie są imponujące (szacowane na około $20 \mathrm{mld} \mathrm{m}^{3}$ ). Natomiast istnieją znaczne szanse na znalezienie dużych złóż gazu w głęboko zalegających utworach czerwonego spągowca lub zalegających pod nim utworach karbonu i dewonu (Such et al., 2010), jest również szansa na odkrycie złóż ropy i gazu w głębokich poziomach Karpat fliszowych. Świadczy o tym przykład Ukrainy (Rudko, 2014), która eksploatuje złoża karpackie oraz złoża we wschodniej Ukrainie na głębokościach przekraczających $5000 \mathrm{~m}$ w podobnych do polskich warunkach geologicznych.

\section{Biznesplan}

Wraz ze wzrostem głębokości wzrasta ryzyko poszukiwań. Coraz trudniej interpretować wyniki badań sejsmicznych. Koszty odwiertów gwałtownie rosną. W rezultacie koszty projektów poszukiwawczych będą liczone w setkach milionów złotych. Te aspekty poszukiwań spowodują, że podstawowe znaczenie $\mathrm{w}$ analizie ewentualnie znalezionych złóż będzie miał rachunek ekonomiczny. $Z$ jednej strony koszty odwiertów i ewentualna budowa kopalni, z drugiej - ilość gazu lub ropy, którą można uzyskać. Tak więc pierwszym warunkiem opłacalności będzie wielkość złoża, a drugim - współczynnik sczerpania złoża, zależny od rodzaju i parametrów skały zbiornikowej. Interesujące będą złoża, z których można uzyskać co najmniej $1 \mathrm{mld} \mathrm{m}^{3}$ gazu lub ponad $0,5 \mathrm{mln} \mathrm{t}$ ropy. Przy czym znalezienie takiego złoża jest warunkiem koniecznym, a nie wystarczającym dla opłacalnej eksploatacji. Warunkiem wystarczającym będą odpowiednie, szeroko pojęte parametry petrofizyczne i geometryczne złoża.

\section{Szeroko pojęte parametry petrofizyczne i geometryczne złoża}

Parametry te będą obejmować - oprócz parametrów filtracyjnych i zbiornikowych skał tworzących złoże oraz parametrów medium złożowego - również kształt złoża (geometrię) (rys. 1).

A. Kształt złoża. Takie parametry jak powierzchnia złoża, jego miąższość i regularność kształtu będą miały istotny wpływ na liczbę projektowanych odwiertów eksploatacyjnych i ich konstrukcję (pionowe, poziome) (Łętkowski, 2019). Przy kosztach jednego odwiertu sięgających $100 \mathrm{mln}$ zł (w przypadku odwiertów poziomych z wielokrotnym szczelinowaniem ten koszt będzie zdecydowanie wyższy od tej wartości) będzie to jeden z podstawowych parametrów opłacalności eksploatacji. Dopiero opracowanie modelu dynamicznego złoża i precyzyjne umiejscowienie potencjalnych odwiertów eksploatacyjnych uzasadni prowadzenie dalszych prac na złożu.

B. Parametry zbiornikowe i filtracyjne skał. Tu również, obok standardowych metod badania parametrów złóż, trzeba będzie zastosować specjalistyczne badania pozwalające na określenie realnych parametrów zbiornikowych i filtracyjnych na dużych głębokościach (Bodi, 2012; Clarkson et al., 2012; Budak et al., 2015), które w warunkach złożowych i na powierzchni mogą się różnić o rząd wielkości. To samo dotyczy istniejących systemów mikroszczelin, których rozwartości są funkcją ciśnień wywieranych na skałę przez płyny złożowe i skały nadkładu (Kaczmarczyk i Lis-Śledziona, 2017).

1. Plan badań powinien obejmować (szczególnie dla złóż typu tight):

- badania porowatości, przepuszczalności, analizy parametrów przestrzeni porowej, przy czym powinny to być analizy wykonywane w symulowanych warunkach złożowych (Such et al., 2015) dla istotnej statystycznie liczby prób i analizy w warunkach powierzchniowych (dla wszystkich dostępnych prób);

- tomografię komputerową;

- badania petrograficzne mające na celu wydzielenie typów skał, ilości cementów, analizę inkluzji fluidalnych, określenie współczynników kompakcji i cementacji (Leśniak et al. 2006; Ziemianin, 2016; Lis-Śledziona i Mroczkowska-Szerszeń, 2020);

- badania sedymentologiczne (Drozd et al., 2019). 
2. Uzyskane wyniki powinny zostać poddane badaniom korelacyjnym i analizom z wykorzystaniem algorytmów sztucznej inteligencji w celu wydzielenia klas podobieństwa skał zbiornikowych (Mirzaei-Paiaman et al., 2018; Porras i Campos, 2018; Topór, 2020). Wyniki powinny odpowiedzieć na pytanie, które klasy podobieństwa mają takie parametry, że dla uzyskania rzetelnych wyników wystarczą ich analizy w warunkach powierzchniowych, a które muszą być przebadane w symulowanych warunkach złożowych (tu szczególnie wrażliwym parametrem będzie przepuszczalność) (Amaefule et al. 1993; Lis-Śledziona, 2019).

3. Kolejnym etapem będzie korelacja uzyskanych wyników z wynikami geofizyki otworowej (Burmester, 2019).

4. Rezultatem przeprowadzonych badań powinno być opracowanie numerycznego modelu złoża na podstawie wszystkich zintegrowanych wyników badań: od geologii i sejsmiki do wyników badań laboratoryjnych.

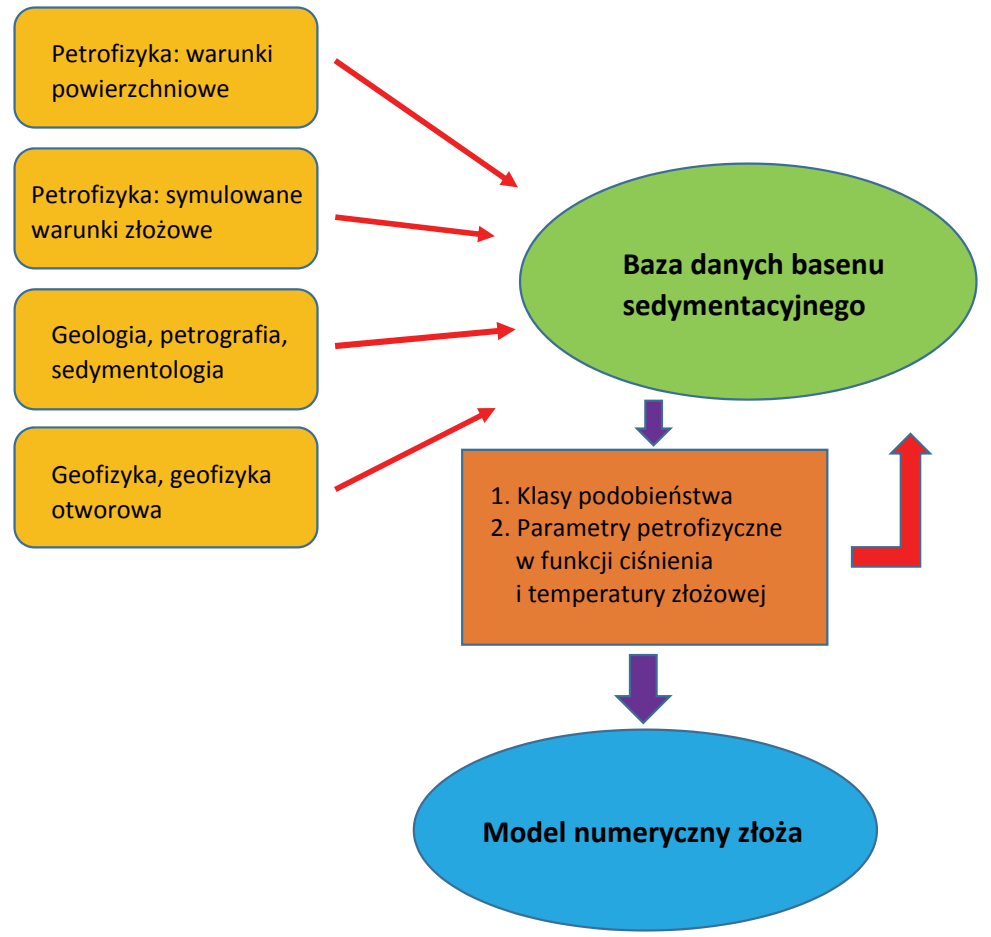

Rys. 1. Schemat badawczo-korelacyjny dla modeli numerycznych złóż z dużych głębokości

Fig. 1. Correlation and investigation sketch for numerical models of depth reservoirs

\section{Model dynamiczny i zaprojektowanie produkcji}

Ten element będzie wymagał wykonania kolejnego bloku analitycznego, obejmującego:

- badania przepływów fazowych - będą to badania w symulowanych warunkach złożowych z zastosowaniem oryginalnych płynów złożowych (Such, 2019);

- badania relacji skała-woda (m.in. pęcznienie minerałów ilastych) (Such et al., 2015);

- analizę konieczności wykonania szczelinowań i ewentualne wykonanie badań niezbędnych do zaprojektowania szczelinowania (Kaczmarczyk i Lis-Śledziona, 2017);

- analizy geomechaniczne (Słota-Valim, 2014).

Wykonanie tych badań pozwoli na stworzenie modelu dynamicznego obejmującego takie elementy jak: oszacowanie liczby i rodzaju wierconych odwiertów (pionowe, poziome, skośne), oszacowanie wielkości produkcji.

\section{Analiza ekonomiczna}

Przy głęboko zalegających złożach jest to absolutnie kluczowy element. Opłacalność eksploatacji zależeć będzie od takich czynników jak: wielkość złoża, przepuszczalność skał, liczba odwiertów niezbędnych do wykonania i potencjalna wielkość produkcji. Będzie to również ciągły proces rozłożony na etapy, przy czym do eksploatacji dojdzie jedynie w przypadku, jeśli ostateczny rachunek ekonomiczny wypadnie pozytywnie:

- pierwszą analizę wykonuje się po odwierceniu pierwszego odwiertu poszukiwawczego. Mając zinterpretowane dane sejsmiczne, wyniki profilowań geofizycznych w odwiercie i wyniki badań laboratoryjnych oraz odpowiednią bazę danych, można wstępnie oszacować ilość gazu lub ropy do uzyskania (Burmester, 2019);

- jeśli analiza ekonomiczna wypadnie pozytywnie, projektuje się następne odwierty rozpoznawcze i na ich podstawie opracowuje się model geologiczny złoża (rys. 1), jak również szacuje ilość węglowodorów do uzyskania;

- ostatnim etapem jest stworzenie modelu dynamicznego i przeprowadzenie ostatecznej analizy ekonomicznej. Analiza ekonomiczna obejmuje takie problemy jak: koszty z poszczególnych odwiertów, liczba odwiertów do wykonania, ewentualne zabiegi stymulacyjne, takie jak szczelinowanie, a także oszacowanie kosztów infrastruktury powierzchniowej.

\section{Big data}

Przedstawiony powyżej plan badań można zmodyfikować tak, by skrócić czas badań i ograniczyć koszty, w jeden sposób. Krytycznym elementem są badania w symulowanych 


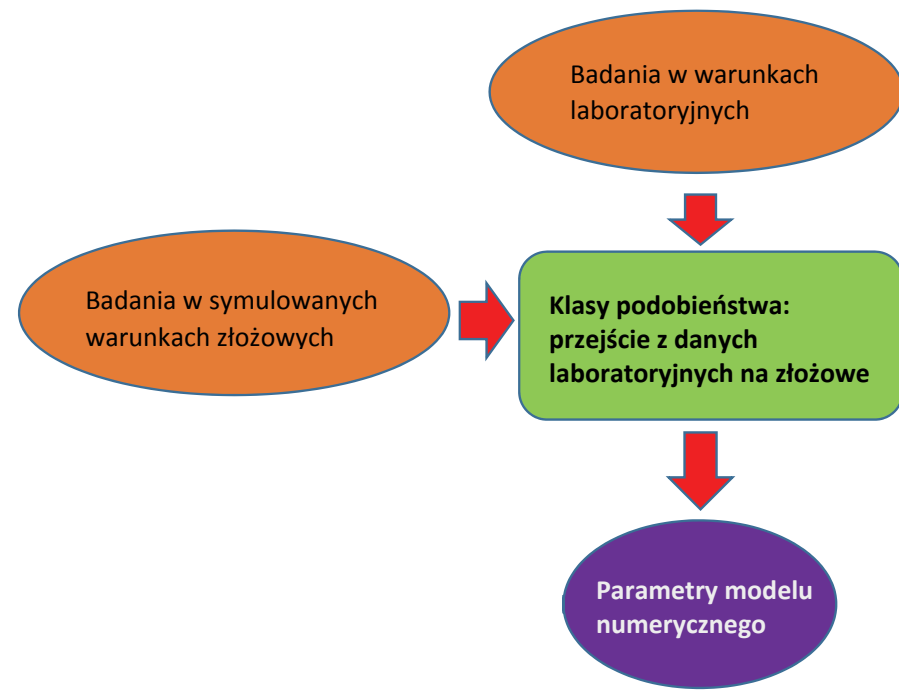

Rys. 2. Sposób oszacowania danych petrofizycznych w warunkach złożowych

Fig. 2. Evaluation of petrophysical data under reservoir conditions

warunkach złożowych. Są one rzetelne, powtarzalne, niezbędne zwłaszcza w przypadku złóż niekonwencjonalnych, natomiast trwają niezwykle długo - jedna analiza (na próbce typu plug) może wymagać nawet kilku dni. W sumie zebranie statystycznie poprawnej liczby pomiarów może trwać bardzo długo. Należy więc zmienić sposób podejścia do rozwiązywania modelowania tego typu złóż. Czas tych badań będzie można skrócić w sposób przedstawiony na rysunku 2 . Optymalnym rozwiązaniem byłoby wykonanie wstępnego modelu złoża na podstawie pierwszego wiercenia. Czy jest to możliwe? Tak, jeśli stworzymy odpowiednie bazy danych dla poszczególnych basenów sedymentacyjnych. Wykorzystując metody sztucznej inteligencji, można dokonać wydzielenia klas podobieństwa skał (rock typing), oszacować parametry skał dla całego złoża i przeprowadzić analizę ekonomiczną na podstawie bazy danych z rozwiercanego basenu sedymentacyjnego oraz wyników badań rdzeni i profili geofizycznych z pierwszego odwiertu.

Kluczowe będzie przygotowanie dla danego basenu sedymentacyjnego odpowiedniej bazy danych (Amaefule et al., 1993; Burmester, 2019; Lis-Śledziona, 2019). Będzie w niej dużo danych (archiwalnych i wykonywanych na bieżąco) zawierających wyniki badań laboratoryjnych. Zostaną one uzupełnione wynikami badań wykonanych w symulowanych warunkach złożowych oraz dostępnymi danymi z badań geofizyki otworowej. Baza będzie zasilana w miarę postępu prac w danym basenie sedymentacyjnym nowymi wynikami wszystkich typów (z koniecznym uwzględnieniem wyników badań wykonywanych w symulowanych warunkach złożowych). Baza stanie się użyteczna w prospekcji, gdy ilość danych wykonywanych w warunkach złożowych przekroczy próg rzetelności statystycznej dla danego basenu sedymentacyjnego. Powinno ich być tyle, aby znaleźć formuły pozwalające oszacować parametry petrofizyczne w warunkach złożowych dla wyników otrzymanych w warunkach laboratoryjnych (rock typing) (Guo et al., 2005; Kerzner i Daniel, 2018). Jeśli takie formuły powstaną, w sposób zdecydowany pozwoli to na skrócenie czasu potrzebnego do określenia parametrów petrofizycznych dla danego złoża, a tym samym do oszacowania liczby otworów i ilości węglowodorów możliwych do wydobycia (rys. 2) (Rushing et al., 2008; Łętkowski, 2019).

Na każdym etapie należy weryfikować poprawność zastosowanych metod obliczeniowych. Chodzi tu o wydzielenie klas podobieństwa (rzetelnych statystycznie) dla opracowywanego złoża, następnie o wykonanie tylu analiz w warunkach złożowych, aby możliwa była weryfikacja poprawności przeliczania parametrów przestrzeni porowych dla danych warunków złożowych.

Skrócenie czasu badań jest niemożliwe w przypadku pierwszego analizowanego złoża $\mathrm{w}$ danym basenie sedymentacyjnym. Należy dla niego wykonać tyle analiz w symulowanych warunkach złożowych, by było możliwe ich poprawne statystycznie zastosowanie w obliczeniach korelacyjnych.

\section{Wnioski}

1. Istnieją realne przesłanki dla znalezienia złóż ropy naftowej i gazu ziemnego na dużych głębokościach w Polsce. O ich opłacalnej eksploatacji zdecyduje rachunek ekonomiczny.

2. Metodyka badań (nawet w przypadku złóż konwencjonalnych o niskiej przepuszczalności) musi uwzględniać parametry petrofizyczne złóż w warunkach złożowych. Jedyną metodą pozwalającą na obniżenie kosztów badań i skrócenie ich czasu jest wykorzystanie baz danych zawierających wyniki badań sejsmiki, badań w warunkach laboratoryjnych i badań w symulowanych warunkach złożowych z odpowiednich basenów sedymentacyjnych i zastosowanie metod korelacyjnych i algorytmów sztucznej inteligencji. Bazy te muszą spełniać warunki kompleksowości (badania w warunkach laboratoryjnych i złożowych) oraz wymagania statystycznej rzetelności.

3. Dzięki opracowanym bazom danym można będzie określić od razu liczbę potrzebnych odwiertów, parametry skał, których rdzeni nie pozyskano podczas wiercenia, a co za tym idzie - będzie można sporządzić wstępny model rozwiercanego złoża.

\section{Literatura}

Amaefule J.O., Altunbay M., Tiab D., Karsedy D.G., Keelan D., 1993. Enhanced Reservoir Description: Using Core and Log data to Identify Hydraulic (Flow) Units and Predict Permeability in Uncored Intervals/Wells. Society of Petroleum Engineers. DOI: 10.2118/26436-MS. 
Bodi T., 2012. Gas flow in the nano size pore channels of tight and non conventional gas storage formation. Geosciences and Engineering, 1: 49-63.

Budak P., Cicha-Szot R., Leśniak G., Majkrzak M., Such P., 2015. Threshold pressure in tight gas reservoir of Central European formations. International Symposium of the Society of Core Analysts held in St. John's Newfoundland and Labrador, Canada, SCA2015-058: 1-7.

Burmester G., 2019. High Resolution Petrophysics - Wellbore Images as Big Data Source for Reservoir Engineering and Production Technology. 81 $1^{\text {st }}$ EAGE Conference and Exhibition. DOI: 10.3997/2214-4609.201900980.

Clarkson Ch.R., Wood J., Burgis S., Aquino S., Freeman M., 2012. Nanopore structure analysis and permeability prediction for a tight gas siltstone reservoir by use of low-pressure adsorption and mercury-intrusion techniques. Society of Petroleum Engineers. DOI: 10.2118/155537-PA.

Drozd A., Dziadzio P., Stadtmüller M., 2019. Wykształcenie facjalne i korelacja profili warstw krośnieńskich z odsłonięć i otworów wiertniczych (fałd Gorlic, jednostka śląska, Karpaty). Nafta-Gaz, 11: 663-673. DOI: 10.18668/NG.2019.11.01.

Guo G., Diaz M.A., Paz F., Smalley J., Waniger E.A., 2005. Rock typing as an effective tool for permeability and water saturation modelling: a case study in a clastic reservoir in the Oriente Basin. Society of Petroleum Engineers. DOI: 10.2118/97033-PA.

Kaczmarczyk W., Lis-Śledziona A., 2017. Adaptation of methodology of Discrete Fracture Network (DFN) model building for selected lower Paleozoic intervals. Nafta-Gaz, 11: 843-850. DOI: 10.18668/NG.2017.11.03.

Kerzner M., Daniel P.J., 2018. Big Data in Oil \& Gas and Petrophysics. [W:] Srinivasan S. (ed.). Guide to Big Data Applications. Studies in Big Data. Springer, Cham., 26. DOI: 10.1007/978-3-319-53817-4.

Leśniak G., Biernacka J., Buniak A., 2006. Wpływ kompakcji i cementacji na właściwości zbiornikowe piaskowców eolicznych czerwonego spągowca z obszaru monokliny przedsudeckiej. Prace Instytutu Nafty i Gazu, 134: 1-67.

Lis-Śledziona A., 2019: Petrophysical rock typing and permeability prediction in tight sandstone reservoir. Acta Geophysica, 67: 1895-1911. DOI: 10.1007/s11600-019-00348-5.

Lis-Śledziona A., Mroczkowska-Szerszeń M., 2020. Wpływ zailenia na wartości parametrów sprężystych w osadach miocenu. Nafta-Gaz, 1: 18-28. DOI: 10.18668/NG.2020.01.03.

Łętkowski P., 2019. Optimization algorithm for number and wells placement. Nafta-Gaz, 12: 744-750. DOI: 10.18668/ NG.2019.12.02.
Mirzaei-Paiaman A., Ostadhassan M., Rezaee M.R., SaboorianJooybari H., Chen Z., 2018. A new approach in petrophysical rock typing. Journal of Petroleum Science and Engineering, 166: 445-464. DOI: 10.1016/j.petrol.2018.03.075.

Porras J.C., Campos O., 2018. Rock Typing: A Key Approach for Petrophysical Characterization and Definition of Flow Units. Society of Petroleum Engineers. DOI: 10.2523/69458-MS.

Rudko G.I. (ed.), 2014. Energy resources of geological environment in Ukraine. State Commission of Ukraine on Mineral Resources, Kijów.

Rushing J.A., Newsham K.E., Blasingame T.A., 2008. Rock Typing: Keys to Understanding Productivity in Tight Gas Sands. Society of Petroleum Engineers. DOI: 10.2118/114164-MS.

Słota-Valim M., 2014. Projektowanie wtórnego zabiegu udostępniania złóż typu niekonwencjonalnego $\mathrm{z}$ uwzględnieniem geomechanicznego modelu Ziemi. Nafta-Gaz, 9: 563-573.

Such P., 2019. Oil and Gas in Poland: critical points and future prospecting. IOP Conf. Series: Earth and Environmental Science, 261. DOI: $10.1088 / 1755-1315 / 261 / 1 / 012050$.

Such P., Dudek L., Mroczkowska-Szerszeń M., Cicha-Szot R., 2015. The influence of reservoir conditions on filtration parameters of shale rocks. Nafta-Gaz, 11: 827-832. DOI: 10.18668/ NG2015.11.03.

Such P., Leśniak G., Słota M., 2010. Ilościowa charakterystyka porowatości i przepuszczalności utworów czerwonego spągowca potencjalnie zawierających gaz ziemny zamknięty. Przegląd Geologiczny, 58(4): 347-351.

Topór T., 2020. An Integrated workflow for MICP-based rock typing: A case study of a tight - gas sandstone reservoir in the Baltic Basin (Poland). Nafta-Gaz, 4: 219-229. DOI: 10.18668/NG.2020.04.01.

Ziemianin K., 2016. Petrografia i granulometria utworów czerwonego spągowca - wstępna charakterystyka do poszukiwania złóż gazu zamkniętego (tight gas). Nafta-Gaz, 7: 502-512). DOI: 10.18668/NG.2016.07.02

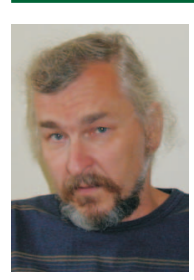

Dr hab. Piotr SUCH, prof. INiG - PIB

Zastępca Dyrektora ds. Poszukiwań Złóż

Węglowodorów

Instytut Nafty i Gazu - Państwowy Instytut Badawczy ul. Lubicz 25 A

31-503 Kraków

E-mail: piotr.such@inig.pl 